H Lapierre, H Prud'homme, H Fouchard, L Lebrun, D Hariri (INRA, unité de pathologie végétale, F-78026 Versailles cedex, France)

SBWMV and WYMV have been mostly described in very distant areas in the same country. In fact these 2 viruses are found today in contiguous sites and sometimes in the same field. However so far not much work has been undertaken on interaction between these 2 viruses in wheat. Nevertheless, it has been shown that in the presence of the 2 viruses the resistance of some cultivars (cvs) to SBWMV could be broken down when they are susceptible to WYMV. SBWMV concentration in the shoots of $\mathrm{cv}$ Newton, which shows such a behaviour may be as high as those of susceptible cvs (Lommel et al, 1986).

In France, out of the susceptible cvs of wheat to SBWMV and/or WYMV only $3 \mathrm{cvs}$, Pernel, Promessa and Virlor, were found to be susceptible only to WYMV (WYMVs) whereas the crs susceptible to SBWMV were very frequent.

Under laboratory conditions, these 3 cvs were inoculated by soil carrying SBWMV and revealed a viral concentration in the roots, which might be as high as the susceptible cvs. However, in those 3 cvs there was no migration of the virus in the shoots.

In the field, in soil carrying only SBWMV, this virus was either not detected or was very difficult to detect in roots of these cvs. No foliar symptoms were observed and the virus was not detected in the leaves of the main stem at least up to the spring season.

In the case of co-infection with WYMV, SBWMV is not easily detected in the roots as compared to infection in plants by soil carrying SBWMV only. The plants of these $3 \mathrm{cvs}$ were showing clear-cut mosaic symptoms and had a high WYMV concentration.

The behaviour of cvs Newton and Homestead (another American cV) of the type SBWMVr WYMVS in USA were also studied in France in soils carrying SBWMV, WYMV or both viruses. The behaviour of these cvs was similar in France and the USA using soils carrying only 1 virus species. In soil carrying both viruses SBWMV was not detected in the leaves of the main stem of $\mathrm{cv}$ Homestead. However, in case of the cr Newton, a few plants were found to carry SBWMV during at least one phase of their vegetative growth.

Lommel SA, Willis WG, Kendall TL (1986) Identification of wheat spindle streak mosaic virus and its role in a new disease of winter wheat in Kansas. Plant Dis 70, 964-968

Localisation in situ du maize streak virus (MSV) dans un hybride sensible de maïs et une lignée resistante. $L$ Bigarre ${ }^{1}, M$ Granier ${ }^{1}$, B Reynaud 2, M Nicole ${ }^{3}, \mathrm{M}$ Peterschmitt 1 $\left({ }^{1}\right.$ CIRAD-CA, LPRC, BP 5035, F-34032 Montpellier cedex 1; ${ }^{2}$ CIRAD-CA, 7, chemin de I'IRAT, F-97410 Saint-Pierre; ${ }^{3}$ ORSTOM, laboratoire de phytopathologie, BP 5045, F-34032 Montpellier cedex 1, France)

Les études génétiques de la résistance du maïs à la virose causée par le maize streak virus (MSV) ont abouti à l'hypothèse de 2 systèmes géniques distincts, l'un oligogénique déterminant une résistance totale et l'autre polygénique déterminant une résistance partielle. Le cumul des 2 types de résistance présenterait un avantage indéniable aux plans de la qualité et de la durabilité de la résistance. Pour atteindre cet objectif, une connaissance plus précise des résistances est nécessaire tant au niveau de leur déterminisme génétique que de leurs mécanismes physiologiques. Outre la cartographie des gènes de résistance amorcée récemment, une étude histoet cyto-pathologique a été entreprise sur l'hybride sensible Sabrina et sur la lignée partiellement résistante D212 par observation en microscopie électronique et photonique, et par immunocytochimie.

Au plan cytopathologique, les tissus infectés de l'hybride sensible mais également de la lignée résistante montrent des modifications profondes qui touchent la structure des organelles. Les chloroplastes présentent une désorganisation interne, visible par des relâchements des thylacoïdes et une diminution de la quantité d'amidon. Dans les noyaux, on note une réorganisation importante de la chromatine qui se redistribue principalement à sa périphérie. Les nucléoles sont généralement denses, hypertrophiés et associés à des structures fibrillaires sphériques probablement composées d'acide nucléique.

Le marquage immunocytochimique à l'or colloïdal des protéines de la capside révèle que les virions sont organisés en amas pseudo-cristallins, aussi bien chez l'hybride sensible que chez la lignée résistante. Ils sont localisés dans le noyau et parfois dans le cytoplasme de tous les types cellulaires de la feuille, excepté les vaisseaux du xylème. La résistance ne semble pas avoir d'effet sur la répartition du MSV dans les différents types cellulaires. Les amas de virus 
sont principalement associés aux zones non chlorotiques, mais occasionnellement, il a été remarqué des amas dans des zones non chlorotiques bordant les stries ; ces zones étaient probablement à un stade précoce d'infection.

La densité des inclusions virales a pu être évaluée en microscopie optique sur des coupes semi-fines après marquage à l'or colloïdal et amplification avec un sel d'argent. On détecte au plus, par plan de coupe de feuille de la lignée résistante, une inclusion par faisceau vasculaire (y compris le mésophyle et l'épiderme voisins), alors que l'on en détecte jusqu'à 6 chez une plante sensible. Cette différence suggère une résistance à la multiplication du virus.

\section{Complexity in evaluating resistance of barley (Hordeum vulgare L) to 2 pathotypes of BYDV-PAV: allelic variability at the Yd2 gene} locus. BA Chalhoub ${ }^{1 *}$, A Sarrafi ${ }^{3}$, HD Lapierre ${ }^{2}$ ( 1 INRA, unité de génétique et amélioration des plantes; 2 INRA, unité de pathologie végétale, INRA, route de Saint-Cyr, F-78026 Versailles cedex; ${ }^{3}$ ENSA, laboratoire de biotechnologie et amélioration des plantes, 145, avenue de Muret, F-31076 Toulouse cedex, France)

The inheritance of resistance in barley (Hordeum vulgare L) to 2 pathotypes of the PAV-serotype of barley yellow dwarf virus (BYDV) was investigated. Six barley lines, which differ in their response to pathotypes $R G$ and $2 t$ of BYDVPAV, were utilised in this study. Vixen, carrying the $Y d 2$ gene of resistance and $80-81 B Q C B 10$ are partially resistance to both pathotypes in growth chamber and field tests. Chikurin Ibaraki 1 and Carré d'hiver are susceptible to isolates $2 t$ only in field conditions, whereas Plaisant and Ea52 (which is an induced mutant of Chikurin Ibaraki 1) are susceptible to both isolates.

Crosses were made among these cultivars and the $F 1$ and $F 2$ plants were tested against the 2 BYDV-PAV pathotypes in both growth chamber and field conditions.

\section{Segregations against the pathotype $R G$}

All F2 plants from crosses between the genotypes Vixen, 80-81BQCB10, Chikurin Ibaraki 1 and Carré d'hiver were resistant to isolate $R G$ in growth chamber and field conditions. The F2 plants from crosses between the susceptible genotypes (Plaisant and Ea52) and the resistant ones (Vixen, 80-81BQCB10, Chikurin Ibaraki 1 and Carré d'hiver) segregate at a ratio of 1 resis- tant to 3 susceptible to the pathotype RG. This suggests that the resistance of each of these cultivars is controlled by single recessive gene.

\section{Segregations against the pathotype $2 t$}

Segregations against isolate $2 t$ in the growth chamber tests were similar to those observed against isolate RG. In field conditions, only Vixen and $80-81 \mathrm{BQCB} 10$ were resistant to isolate $2 \mathrm{t}$, and F2 plants from their cross were always resistant. The F2 plants of crosses between these 2 lines and the other lines segregate in a ratio of 1 resistant to 3 susceptible. All the other F2 plants were susceptible to isolate $2 t$ in field conditions.

These results indicate that $80-81 B Q C B 10$ contains the same gene of resistance as that of Vixen (Yd2). On the other hand, Chikurin Ibaraki 1 and Carré d'hiver contain the same gene of resistance, which is also allelic to the $Y d 2$ gene in Vixen and 80-81BQCB10. However, it differs from the $Y d 2$ gene in Vixen and $80-81 B Q C B 10$ by being overcome by isolate $2 t$ in field conditions.

The nucleotide sequence and proposed genome organisation of oat chlorotic stunt, a new soil-borne virus of cereals. $N$ Boonham ${ }^{1}$, CM Henry ${ }^{2}$, KR Wood ${ }^{1}$ ( 1 School of Biological Sciences, The University of Birmingham, Edgbaston, Birmingham, B15 2TT; ${ }^{2}$ Central Science Laboratory MAFF, Hatching Green, Harpenden, Herts, AL5 2BD, UK)

The complete nucleotide sequence of a new soilborne virus of cereals has been deduced. The genome consists of a monopartite positive-sense single-stranded RNA molecule, of 4114 nucleotides in length. The genome contains 4 putative open reading frames (ORFs). The first ORF at the 5 '-end of the genome (ORF1) encodes a protein with a predicted $M_{r}$ of $23476 \mathrm{kDa}$ (p23). The second ORF is punctuated by the amber termination codon of ORF1 and encodes a protein of predicted $M_{\mathrm{r}}$ of $84355 \mathrm{kDa}$ (p84). The third ORF (ORF3) is situated at the 3'end of the genome and encodes a protein of predicted $M_{\mathrm{r}} 48231 \mathrm{kDa}$ (p48). The final ORF (ORF4) is nested within ORF3 and codes for a protein with predicted $M_{r}$ of $8220 \mathrm{kDa}(\mathrm{p} 8)$. The functions of ORF2 and ORF3 have been established; ORF2 contains amino acid sequence motifs characteristic of the RNA-dependent RNA polymerases of positive-strand RNA viruses. ORF3 has been identified as the coat protein both by direct peptide sequencing and also 